
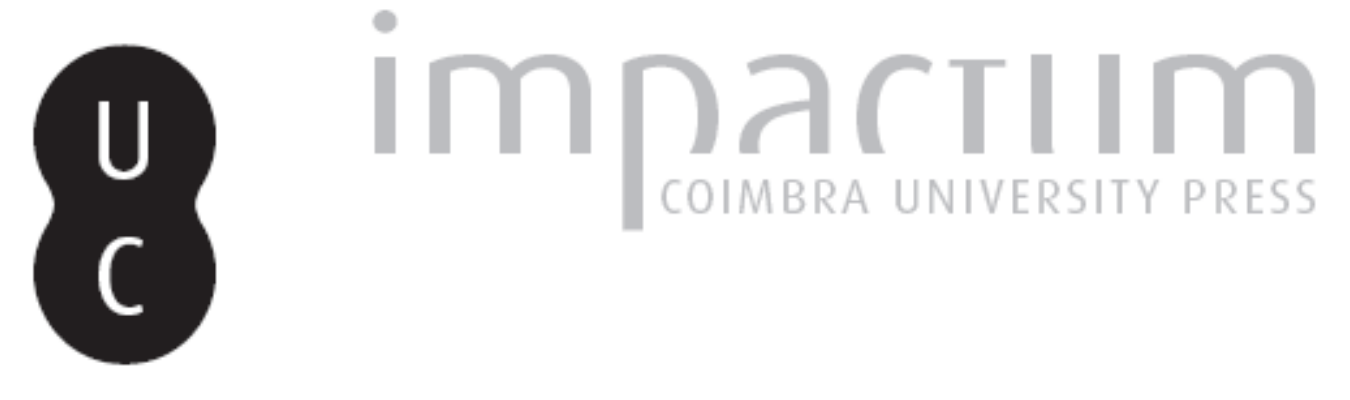

Um caso exemplar: cenáculo e o coleccionismo no Portugal de setecentos

Autor(es): $\quad$ Morais, Rui

Publicado por: Centro de História da Universidade de Lisboa

URL persistente:

URI:http://hdl.handle.net/10316.2/23788

DOI:

DOI:http://dx.doi.org/10.14195/0871-9527_19_11

Accessed : $\quad$ 26-Apr-2023 13:48:57

A navegação consulta e descarregamento dos títulos inseridos nas Bibliotecas Digitais UC Digitalis, UC Pombalina e UC Impactum, pressupõem a aceitação plena e sem reservas dos Termos e Condições de Uso destas Bibliotecas Digitais, disponíveis em https://digitalis.uc.pt/pt-pt/termos.

Conforme exposto nos referidos Termos e Condições de Uso, o descarregamento de títulos de acesso restrito requer uma licença válida de autorização devendo o utilizador aceder ao(s) documento(s) a partir de um endereço de IP da instituição detentora da supramencionada licença.

Ao utilizador é apenas permitido o descarregamento para uso pessoal, pelo que o emprego do(s) título(s) descarregado(s) para outro fim, designadamente comercial, carece de autorização do respetivo autor ou editor da obra.

Na medida em que todas as obras da UC Digitalis se encontram protegidas pelo Código do Direito de Autor e Direitos Conexos e demais legislação aplicável, toda a cópia, parcial ou total, deste documento, nos casos em que é legalmente admitida, deverá conter ou fazer-se acompanhar por este aviso.

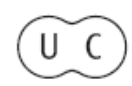



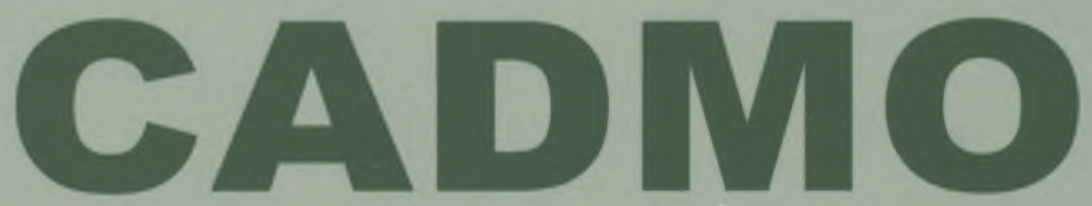

Revista de História Antiga

\author{
Centro de História \\ da Universidade de Lisboa
}

19

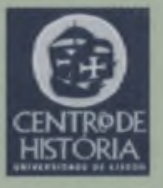

430 =

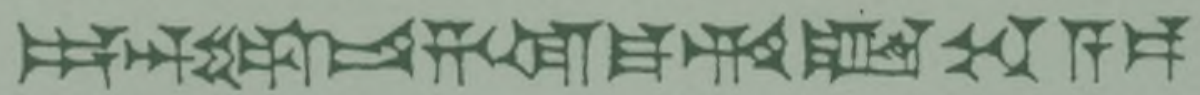

MHNIN AEI $\Delta$ E $\Theta E A ~ \Pi H \Lambda H I A \triangle E \Omega$ 


\title{
UM CASO EXEMPLAR: CENÁCULO E O COLECCIONISMO NO PORTUGAL DE SETECENTOS
}

RUI MORAIS

Universidade de Minho rmorais@uaum.uminho.pt

\begin{abstract}
"Pode verdadeiramente considerar-se como o restaurador dos estudos de humanidades em Portugal D. Frei Manuel do Cenáculo Villas Boas..."

Emilio Hübner, Notícias Archeológicas de Portugal, 1874, p. 5.
\end{abstract}

\section{Resumo}

Neste estudo realça-se o caso edificante de um dos maiores vultos do Portugal de Setecentos. Depois de uma breve referência ao carácter enciclopedista de Frei Manuel do Cenáculo, destaca-se a sua importância enquanto coleccionador e interessado pelas actividades arqueológicas. Apresenta-se, ainda, um enquadramento do tema do coleccionismo numa época em que floresciam os intercâmbios entre eruditos e antiquários, em parte impulsionados pela corrente do Grand Tour.

Palavras-chave: Frei Manuel do Cenáculo; Coleccionismo; História da Arqueologia.

\section{Abstract}

In this study we point out the enlightening case of one of the major figures of the $18^{\text {th }}$ century Portugal. After a brief reference to Frei Manuel do 
Cénaculo's encyclopedic character, we highlight his importance as a collector and as someone deeply interested in archaeological activities. We also contextualize the theme of collecting in an age in which the exchange of information among scholars and antiquarians flourished, driven in part by the Grand Tour tradition.

Key-words: Frei Manuel do Cenáculo; Coleccionism; History of Archaeology.

Uma das personalidades mais marcantes do nosso Portugal de Setecentos foi o famoso arcebispo D. Frei Manuel do Cenáculo de Villas Boas Anes de Carvalho. De origem modesta, nasceu em Lisboa a 1 de Março de 1724, no seio de uma família de pequenos artesãos, e veio a falecer em Évora, como bispo desta arquidiocese, a 26 de Janeiro de 1814, na avançada idade de 90 anos incompletos, logo após as invasões francesas.

Passados 285 anos sobre o seu nascimento, vários são os estudos e ensaios sobre esta figura ímpar do iluminismo português. De entre estes, destaque-se o trabalho pioneiro de F. Gama Caeiro (1959), onde o autor caracteriza Cenáculo como «homem da sua época por excelência" que exerceu, com um enciclopedismo tão ao gosto do seu século, "as mais variadas actividades como historiador, político, eclesiástico, reformador, pedagogo e filósofo, distinguindo-se como humanista, arqueólogo e bibliófilo, cultivando a numismática, a paleografia, o árabe, o siríaco, o aramaico, a teologia, a exegese, a hermenêutica e a liturgia" (Caeiro 1959: 115). Nesta obra, como em outras mais recentes, pode encontrar-se o percurso de excelência, a todos os títulos edificante, desta figura ímpar.

Cenáculo foi sobretudo um grande fundador de bibliotecas ${ }^{(1)}$. O seu nome está associado à fundação de quatro bibliotecas: a Biblioteca do Convento de Jesus em Lisboa, hoje da Academia Real de Ciências; a Biblioteca da Real Mesa Censória, hoje Biblioteca Nacional de Lisboa; a Biblioteca do Palácio Episcopal de Beja, com mais de 9000 volumes, hoje Biblioteca Pública daquela cidade; a Biblioteca de Évora, a actual Biblioteca Pública eborense, que à época contava com mais de 50 mil volumes. Para esta última, reservou a ala ocidental do palácio episcopal, espaço anteriormente usado como Colégio dos Meninos do Coro da Sé ligado por um passadiço ao resto do edifício, e nela instalou um espaço museológico - que posteriormente seria o Museu Regional daquela cidade (Vaz 2006: 60). O modelo seguido por Cenáculo 
foi o de Ângelo Maria Querini, bispo de Brescia, criador e doador de uma biblioteca-museu (1750).

Num documento depositado na Biblioteca Pública de Évora, intitulado Oração do Museu dita a 15 de Março de 1791, da autoria de Frei José de São Lourenço do Valle, revisto e anotado pelo próprio Cenáculo, pode ler-se um passo de especial importância para a história do coleccionismo e dos museus setecentistas:

Tudo isto, senhores, que ouvis dizer - Museu - eram escolas gerais que se governavam por Mestres e encerravam Livrarias com todo o género de objectos em que se podia estudar. Ali, digo tudo, o melhor livro, todas as memórias dos tempos, todas as preciosidades raras da natureza e do engenho das ciências e artes dos homens se guardavam para neles se aprender o que não convém ignorar... (apud Brigola 2006: 48; 2009: 42-46).

Este acontecimento assinala a inauguração do primeiro museu público de história natural dedicado à arqueologia, o Museo Sizenando Cenaculano Pacense ${ }^{(2)}$. Cenáculo havia reunido uma colecção de cerca de 160 lápides de toda a espécie, além de fragmentos de escultura e arquitectura e de numismas e objectos de cerâmica, que mais tarde iriam constituir parte do espólio da colecção da Biblioteca Pública de Évora $^{(3)}$. Na obra de João Carlos Pires Brigola, Colecções, Gabinetes e Museus em Portugal no século XVIII (Lisboa 2003: 429), pode ler-se uma interessante frase que havia sido proferida por Frei Manuel do Cenáculo, quando ainda era arcebispo de Beja e expôs pela primeira vez as suas colecções no edifício da antiga ermida de S. Sezinando, entre o colégio jesuítico de Beja e a Igreja de S. Salvador:

Essas pedras quebradas, dinheiros pisados, letras desconhecidas, e peças desenterradas são preciosos meios que, conhecendo-os, vós sabereis o muito que se ignora.

Nas colecções reunidas neste museu incluíam-se, além de peças arqueológicas, várias espécies de etnografia de diferentes épocas e de história natural (Caeiro 1959: 109). No referido texto, proferido na data de inauguração do museu, pode ainda ler-se a concepção ideal daquele tipo de instituição, encarado como espaço aberto à aprendizagem de um público vasto e já não apenas reservado aos sábios:

No estudo das raridades dos engenhos não se consideram os metais e pedras nuas, mas ilustradas com várias figuras, emblemas, símbolos, 
tipos, inscrições com o que a asserção do estudo anda sempre unida. Nada há mais agradável do que ver os retratos dos antigos heróis, contemplar enigmas, conhecer troféus, ver as façanhas e louvores deixados aos séculos. E de que nasce a utilidade de com esta lembrança excitar-se o desejo de imitar aqueles a quem o mundo deve honra e a posteridade veneração e a história o seu esplendor. Estes documentos tão respeitáveis são a testemunha dos tempos, luz da verdade, vida da lembrança, mestra da prudência e correios da antiguidade que acendem luzes da História, e guiam para a exacta cronologia (apud Brigola 2006: 49).

Cenáculo pretendia transformar esta diocese numa espécie de pólo cultural. Como coleccionador beneficiou de uma rede de intermediários no país e no estrangeiro (Vaz 2009: 13).

Num outro documento, igualmente datado de 1791, Cenáculo expressa a importância dos museus e das bibliotecas na educação e formação da juventude:

Bom é enfim criar os mancebos em princípios direitamente concebidos: exercitá-los nas coisas sabidas: fazer que vão granjeando novas espécies com diligência e muita ordem: radicar-Ihes com modéstia e verdade a emulação e ânimo dócil: confirmá-los na decência da vida e porte de pessoas bem-educadas e amigos da justiça na honra de seus desempenhos, na fidelidade e suas promessas e vocações. Recapitulando o que havemos dito sobre os preparatórios para as ciências não há motivo para que se entenda serem necessários livros infinitos naquela idade. Um escrito pouco mais que um índice das espécies das Belas-Artes e das notícias que não pertencem ao estudo principal e uma colecção de definições e caracteres de tais coisas, é bastante à mocidade de outro emprego como preparatório, sendo contudo ajudada com a comunicação aturada de pessoas eruditas e assistência frequente em Livrarias e Museus, onde concorram sábios a quem se escute; pois estas casas são na verdade feliz escola de aprender costumes e erudição, e de se convencerem os homens ser-lhes necessário ter olhos bem ajustados aos objectos, seja nas Faculdades Maiores, seja nas Belas-Letras, seja nas ocasiões de verem pinturas, obras de escultor e quaisquer outros objectos da Ordem Física de engenho e de imaginação. Isto Ihes será bastante para quando passearem nos campos saberem entender-se com as criaturas em sua própria linguagem: para fazerem diferença nos objectos científicos do que Ihes seja substancial ou acidental, e a tudo ajustar os devidos conceitos (apud Brigola 2009: 40). 
Quando Cenáculo assume o arcebispado metropolitano de Évora leva parte deste espólio, algum do qual extraviado aquando do saque desta cidade no dia 13 de Julho de 1808 pelo exército francês. $\mathrm{Na}$ biblioteca de Évora existem ainda sob o número CXXIX, 1, 13, e com o título de Museo Sizenando Cenaculano Pacense, desenhos exactos de todas as ditas inscrições, feitos, ao que parece, por Félix Caetano da Silva.

Como recentemente bem salientou Maria Helena da Rocha-Pereira (2008: 48), num texto de catálogo intitulado Os vasos gregos: caminhos e descaminhos do coleccionismo português, estava-se então numa época de grandes novidades. Lembra a autora a carta de um sobrinho de Cenáculo, datada de 1803, que de Londres lhe fez saber "a maior novidade literária do momento", a famosa Pedra de Roseta (descoberta no Egipto em 1799 durante a expedição de Bonaparte), que, como o mesmo adverte, "excitará a sagacidade dos antiquários para achar a chave da língua hieroglífica".

Apenas um ano antes, o papa Pio VII, no quirógrafo de 1 de Outubro inserido no édito do Pro Camerlengo cardeal Giuseppe Dória-Pamphili, sintetiza de modo assaz eficaz a relação entre os vestígios antigos (neste caso da própria cidade de Roma) e os comerciantes, os artistas e os eruditos, que se interessavam pelo vasto mercado artístico e antiquário que em muito contribuía para o conhecimento da modernidade (Benocci 2006: 83). Tudo parecia rodar à volta destes visitantes, que alimentavam um vivo mercado de artefactos arqueológicos, bem como de restauradores e copistas. Neste clima, muitas das antigas famílias, com dificuldades económicas, tentavam desfazer-se dos seus bens, o que levava à fragmentação do património artístico familiar (Arata 2008: 61). O governo papal, já com o anterior papa Pio $\mathrm{VI}$, tentava controlar este fenómeno da saída de antiguidades através da criação de licenças de exportação para quem quisesse levar peças antigas para fora do Estado(4). A situação chegou a um tal ponto que, no édito atrás referido, o papa Pio VII promulgará (sem grande sucesso) a interdição de venda de objectos antigos ao estrangeiro (Melegati 2008: 105).

São também conhecidos organismos da tutela entretanto criados para evitar o depauperamento do património histórico, artístico e arqueológico. É o caso do Comissariado para as Antiguidades e do já referido Camerlengo que administrava os bens do Sacro Colégio através de leis especiais, intituladas licentiae extrabendi e patentes extrabendi (Arata 2008: 62). Muitas das obras saídas de Roma como 
consequência da pilhagem efectuada pelo exército napoleónico (18 de Junho de 1796), irão ser devolvidas depois do Congresso de Viena ( 9 de Junho de 1815), em parte graças às pressões de Antonio Canova, encarregue pelo papa Pio VII de fazer reentrar em Roma as obras deportadas (Arata 2008: 70).

Como se depreende, o esforço de Frei Manuel do Cenáculo insere-se num contexto internacional em que os membros da Igreja demonstravam interesse em apoiar e estimular a arqueologia, como forma de legitimação da sua própria instituição, como dever público de promoção do conhecimento. Os papas e os altos funcionários vaticanos eram clérigos cultivados, cada vez mais conscientes da importância dos sítios arqueológicos e da arte antiga no fomento de um turismo de elite, que tanto beneficiava os Estados Pontifícios e ajudava na difusão de uma imagem humanista do papado (Dyson 2008: 30).

Vivia-se uma época em que floresciam os intercâmbios entre eruditos e antiquários, uma tradição já secular com inícios nos finais do século XV em países como a Itália, a Alemanha, a Inglaterra, a França e a Espanha (Mora 2006: 436; Rocha-Pereira 2008: 48). Entre nós, essa tradição parece inaugurar-se no século XVI com André de Resende, que reuniu um número considerável de inscrições romanas, embora desde os comentários de E. Hübner ao Corpus Inscriptionum Latinarum se saiba que nem todas são autênticas (Encarnação 1994: 193-221; 1997: 51-60; Fernandes 1996: 30-32).

No século XVII o desenvolvimento do antiquarismo contribuiu para enriquecer este diálogo. Uma boa parte da colecção de Frei Manuel do Cenáculo foi reunida na segunda metade do século XVIII, ainda antes de ter assumido o arcebispado de Évora. Como acontece com a grande maioria das antigas colecções, públicas e privadas, não é possível saber-se hoje com exactidão a dimensão total da sua colecção. Certamente muitas peças se perderam nos séculos XIX e XX, fruto de insuficiente registo e da dispersão do espólio entre as cidades de Évora e Beja.

É neste contexto cultural que se deve entender a criação e apetrechamento de bibliotecas, onde se reuniram obras muitas diversificadas e percorrendo vastas áreas do conhecimento e saber de seu tempo, caso de edições coevas de Rousseau, Voltaire, Winckelmann, Ulloa, Ustariz, Beccaria, Savary, entre outras (Vaz 2004: 483-498).

Para o tema em análise, destaque-se a figura do saxão Johann Joachim Winckelmann (1717-1768). Sabemos que Cenáculo possuía na sua biblioteca as principais obras deste seu contemporâneo ${ }^{(5)}$, 
socorrendo-se dos seus ensinamentos e citando-o abundantemente (BPE., CXXVIII/1-13, n. ${ }^{\circ}$ 4317, 18 Junho de 1788, apud Marcadé, 1978: 238, nota 258). Winckelmann foi um famoso erudito do Norte da Alemanha, considerado por muitos como o pai da arqueologia e da história de arte modernas. Winckelmann estudou a Antiguidade clássica no seu país para depois se mudar para Roma, onde se converteu no bibliotecário do cardeal Alessandro Albani (1692-1779), poderoso prelado e um dos maiores coleccionadores de antiguidades do seu tempo (Rochebrune, 2008: 15). Graças a esse cargo, Winckelmann teve à sua disposição uma das melhores colecções privadas de antiguidades de Roma e beneficiou da estimulante atmosfera de um dos centros intelectuais mais importantes da cidade. Mais tarde, em 1763, foi nomeado antiquário do papa, título que o converteu no principal responsável pela arqueologia de Roma, até à sua morte brutal em 1768.

A relação de Frei Manuel do Cenáculo com a arqueologia deve, pois, ser devidamente contextualizada. Vivia-se em Portugal um momento privilegiado, com a criação, por D. João V, da Real Academia de História, por real decreto de 20 de Agosto de 1721. Definia-se, pela primeira vez, a verdadeira importância do património histórico e sublinhava-se a importância dos monumentos e da cultura material no estudo do passado (Caetano 2005: 50). José Leite de Vasconcelos atribui a esta iniciativa de conservação ex-situ de monumentos antigos a designação de "primeiro museu nacional de Arqueologia". Qualquer acto de "desattençaõ, negligencia, ou mallcia", era punido por este diploma joanino(6). A tutela das antiguidades encontradas no país passava a ser atribuição da Academia, sendo as câmaras municipais responsabilizadas pela sua salvaguarda. Apoiada financeiramente por subvenção real, a Academia podia decidir pela aquisição de novas antiguidades, especialmente no caso dos bens mais sensíveis como os metais (Brigola 2009: IX). Recorde-se que, apenas dezassete anos mais tarde, em 1738, é fundada a Real Academia de História de Madrid, por «Real Orden» de Felipe V. Desde cedo, estas duas academias, fundadas sob auspícios régios, tiveram profícuas relações e envolveram contactos entre académicos e especialistas, um dos quais Cenáculo, membro efectivo das duas academias. Para além destas academias, especialmente ligadas ao antiquarismo e à arqueologia, e às quais Cenáculo fez, por diversas vezes, doações generosas, deve ainda realçar-se a sua integração na Academia Literária da Baía, no Brasil, e a sua elevação, em 1812, a membro de honra da Academia Real das Ciências (Marcadé, 1978: 23; 241, nota 274; 477, nota 228). 
Recorde-se que a criação de academias era uma prática em fomento na Europa desde o século anterior (Patrocínio, 2007-2008: 101).

Crê-se que na formação de Cenáculo, ainda como franciscano, foi determinante a sua viagem a Roma para assistir em $1750^{(7)}$ ao Capítulo Geral da sua Ordem de S. Francisco ${ }^{(8)}$. Nessa viagem, teria usufruído da companhia de seu mestre, D. Frei Joaquim de São José(9), figura importante na formação de Cenáculo - à data ainda um jovem professor de Coimbra. Sobre a importância desta viagem falaremos mais adiante ${ }^{(10)}$.

No seu percurso por Espanha, Cenáculo ficara impressionado com o Gabinete de Antigüedades de la Real Biblioteca de Madrid e com a Universidade de Alcalá; passou depois para França pelo Roussillon, Languedoc e Dauphiné. Em Itália entusiasma-se com a Universidade de Turim e o Instituto Speculla de Bolonha. Neste périplo, certamente imbuído das correntes associadas ao Grand Tour ${ }^{(11)}$, pôde ainda visitar outros locais, caso de Badajoz, Córdova, Valência, BarceIona e Milão. A visita e passagem por estes locais enquadravam-se no espírito de uma época em que as viagens deviam ser encaradas como formação, meio de enriquecimento do intelecto e convicção profunda de que a comparação de realidades diferentes desenvolvia as capacidades perceptíveis do indivíduo, uma espécie de enriquecimento e de lucidez intelectual.

No regresso dessa viagem, Cenáculo ocupar-se-á da regência de uma cadeira de Teologia na vetusta Universidade de Coimbra, que ocupará desde 1751 até 1755 . Como lente desta Universidade, ensinou aos seus discípulos o estudo das línguas orientais, tornando-se perito no siríaco, no aramaico e no árabe, como já o era no grego e latim. Mais tarde, em 1757, e após o regresso a Lisboa como cronista da Província Franciscana, já o prelado possuía uma razoável colecção, que incluía uma série de inscrições e um importantíssimo numerário catalogado (Caetano 2005: 50).

A vasta colecção de numismas por ele reunida enquadra-se perfeitamente no espírito da época. Recordemos o caso da Real Academia de la Historia de Espanha que, desde os seus inícios, teve uma especial predilecção em recolher e conservar moedas de toda a índole. Mais tarde, nos estatutos de 1792, diz-se inclusivamente que o Antiquário daquela instituição deveria ter "particular conocimiento de las antigüedades, principalmente la Numismática" (Chaves Tristán 2006: 161).

Outros locais já referidos, como Bolonha e Milão, foram igualmente importantes na formação e gosto de Cenáculo. Em Bolonha, no 
Instituto Speculla, para além da famosa biblioteca, pôde não só ficar a par do avanço científico no estudo da astronomia e das matemáticas, como inspirar-se na organização espacial de salas abertas para o claustro do antigo Palazzo Poggi, divididas por áreas do saber (Caetano 2005: 50)(12). Em Milão, Cenáculo teria certamente visitado o Imperial Regio Gabinetto Numismatico e a Biblioteca Ambrosiana. Nestas visitas ele certamente apreciou a vasta colecção de moedas do Gabinete (Mora 2006: 449) e se maravilhou com a Biblioteca de catorze mil manuscritos, setenta e dois mil volumes impressos, medalhas, esculturas antigas e os desenhos de engenhos de Leonardo da Vinci. Influenciado por estes gabinetes de antiguidades, Cenáculo reuniu valiosas colecções de moedas e manteve uma profícua relação epistolar com numerosos numismatas (BPE., CXXVII/1-12, ff. 1-58, apud Marcadé 1978: 23). A mais importante foi saqueada de Évora nos inícios de Oitocentos pelas tropas francesas, em data próxima à recente instalação do prelado naquela cidade. Desse saque dá conta o prelado, escrevendo um ano depois um emblemático opúsculo consagrado ao assalto e ocupação da cidade pelas tropas francesas. Sabe-se também que teria enviado à recente fundada Real Biblioteca de Lisboa parte do seu "Gabinete Medalístico", de modo a contribuir para a constituição de um gabinete de antiguidades. Infelizmente parte deste espólio também se perdeu (Domingos, 2006: 12), ainda que algumas peças tivessem transitado para os primeiros núcleos do Museu Etnológico (Patrocínio 2006: 33).

Nesta época, o coleccionismo de moedas estava de facto em voga. A propósito, é interessante lembrar o papel de Dona Teresa Maria Cristina (1822-1889), princesa das Duas Sicílias, irmã de Fernando II, rei de Nápoles, e esposa do último imperador do Brasil, Dom Pedro II de Bragança. Segundo se crê (Mora 2006: 435-457), parte da vasta colecção de numismática de Dámazo Puertas Álvarez, médico do XIV duque de Alba, acabaria por ser adquirida pela futura imperatriz do Brasil (a outra parte foi adquirida pelo Madagliere Vaticano no dia 13 de Dezembro de 1841). A ela se deve a maior parte do espólio de antiguidades depositado no Palácio Real da Quinta da Boa Vista, em São Cristovão, Rio de Janeiro, actual Museu Nacional de Belas Artes daquela cidade. Para além dos numismas, a colecção de antiguidades compreende cerca de 730 objectos da Magna Grécia, etruscos, gregos e romanos (cerâmica, terracota, vidro, bronzes, mármores - como uma magnífica cabeça de Antínoo), provenientes das escavações que a futura imperatriz realizou na cidade etrusca de Veios 
e dos fundos do Museu Real de Nápoles, muitos certamente das cidades romanas de Pompeia e Herculaneum, enviados para o Brasil pelo seu irmão Fernando II a pedido da imperatriz.

No contexto do coleccionismo em Portugal no tempo de Cenáculo, não é demais lembrar a figura de D. Pedro de Sousa e Holstein, futuro primeiro duque de Palmela. Conhecido entre nós como uma das grandes figuras da cultura e do liberalismo português, foi também um destacado político, desempenhando altos cargos diplomáticos no País e no estrangeiro, e um mecenas e coleccionador de arte (RochaPereira 2008: 49). Parte da sua colecção, como no caso dos vasos gregos, teve como origem as aquisições feitas pelos seus antepassados, D. Manuel e D. Alexandre M. Pinto de Sousa e Holstein, e terão dado entrada em Portugal não muito depois de 1834, após a subida ao trono de D. Maria II, a cujo primeiro governo constitucional ele presidiu (id. ibidem). Nos documentos oficiais que referem as exportações de objectos pela "Espanha», podemos constatar a natureza e a quantidade de materiais e respectivos custos. Do vasto elenco das pessoas mencionadas nestes documentos consta D. Pedro de Sousa e Holstein. Aí se alude que, no dia 31 de Agosto de 1804, D. Pedro teria adquirido a mando de S. M. Fidelíssima quatro pequenas mesas em couro e uma estatueta moderna por 95 escudos, peças a serem expedidas por via marítima (Venetucci 2006: 510). Também este diplomata visitou, em 1805, muitos locais em voga já naquela época, como é o caso de Nápoles e do Vesúvio. Destaque-se, pelo seu significado, a viagem de D. Pedro a Roma, como se pode apreciar neste pequeno texto da sua autoria:

O interesse que excitaram no meu ânimo os passeios que, com meu pai e os mais célebres antiquários de Roma, eu dava quase diariamente, visitando as ruínas da capital do mundo, aumentava com a leitura que nesse tempo começava a fazer da História Antiga e Romana (apud Ventura 2001: 45).

O passo que acabamos de citar revela bem o panorama cultural então vivido. Cenáculo teria certamente vivenciado e usufruído das oportunidades que Roma oferecia, um dos lugares sagrados da cultura clássica. Não se tratava de uma viagem exclusivamente de lazer, mas antes um itinerário formativo em que tudo era meticulosamente planificado. Os vestígios do Império Romano, como o Coliseu, o Panteão ou os fora, fascinavam os recém-chegados. 
Também Cenáculo nos deixa uma viva impressão da já referida viagem a Roma que efectuou com o seu mestre, D. Frei Joaquim de São José(13):

A Viagem a Roma em o anno de sincoenta, em que acompanhei o sábio Mestre Fr. Joaquim, me fará sempre apregoar em quaesquer ramos de litteratura, que foi huma disposição efficacíssima para o bem das lettras na Província. As famosas Bibliothecas, que se presentárão à nossa curiosidade nas Cidades eruditas da nossa passagem, levantárão milhares de ideas que se começarão a produzir, e como o tempo hia permittindo. Dava-se lugar, entre livros que pouco mais se haverião de ler, a obras de novo gosto (apud Caeiro 1959: 35-36, nota 72).

A visita a Itália era fundamental. A viagem pelas cidades italianas proporcionava aos seus visitantes uma espécie de museu ao ar livre, pela quantidade de obras de arte, pelo ambiente luminoso e pelas ruínas que testemunhavam um passado formidável. A visita a Itália representava também uma oportunidade para usufruir dos ainda vigentes ideais renascentistas e de um ambiente musical único, em particular nas suas formas teatrais (Ercoli 2008: XIX-XX). É possível que esta viagem tenha despertado em Cenáculo o contacto que ao longo da sua vida irá manter com alguns dos intelectuais da época que viviam em Itália. É o caso da relação epistolar com Leonor da Fonseca Pimentel (1752-1799), conhecida como a "Portuguesa de Nápoles», uma napolitana de origem portuguesa e figura multifacetada, empenhada em diversas áreas (desde a literatura ao jornalismo e política), e que ficou na história por ter defendido ideais liberais que conduziram à revolução e à instauração da breve República Napolitana ${ }^{(14)}$.

De todas a cidades italianas, Roma era efectivamente a mais importante. O centro ecuménico da religião católica, a capital da arte ocidental, o lugar indiscutível da formação artística internacional, "uma das mais acabadas expressões do lluminismo Católico", no dizer de Francisco Gama Caeiro (1959: 38). Aí, Cenáculo teria usufruído da convivência e da permuta de ideias que a ocorrência de sábios a Roma, por altura do jubileu universal, permitia(15). Assim o indica 0 prelado quando declara que "ali se viam e ouviam muito Escritores da ordem, muitos Prelados prudentes e circunspectos, muitos varões doutíssimos, muitos Religiosos de virtudes, muitos Mestres e Doutores Egrégios e final.te todo o bom da Família Seráfica" (apud Caeiro 1959: 44 , nota 94 ). 
Na obra de Arnaldo Pinto Cardoso sobre A presença portuguesa em Roma (2001), constata-se que esta cidade foi destino regular de sucessivas gerações de portugueses que, desde a fundação da nacionalidade, ali se deslocavam como peregrinos, como refugiados ou em missões diplomáticas para defender os interesses da coroa. A Roma, desde os finais do século XIV, de maneira crescente, dirigiam-se os artistas, os arquitectos e os literatos, como imprescindivel fonte de inspiração e modelo a imitar e igualar. As suas ruínas monumentais e as obras de arte, expostas ou encontradas no decurso das incessantes intervenções urbanísticas papais, não cessavam de espantar e de representar um estímulo no estudo das antiguidades, bem como à sua interpretação e conservação (Arata 2008: 61). No final de setecentos, Roma não era só a capital do catolicismo mas também, e sobretudo, o centro da difusão do conhecimento do antigo.

Para Cenáculo a via arqueológica era um modo de reconhecer as raízes e as origens do povo lusitano, quer através dos heróis gregos ou da herança romana, quer através do orientalismo, como conotação bíblica, neste caso como contraposição ao clássico (Patrocínio, 2007-2008: 102). Lembre-se, a propósito, uma frase de Cenáculo numa carta datada de Março de 1791, dirigida a um seu correspondente e confrade, então em Goa, Padre Rodrigo de Sá:

a Vossa Senhoria/ hei de comunicar couzas, e coizas; mas para isto naõ basta ser viajor intellectual; e gostaria vendo o em/ realidade de encontrar aqui as minhas raríssimas lapides hebraicas, grega e ao que muito mais, fenícias/ achadas no meo Territorio (apud Patrocínio, 2007-2008: 100).

A actividade de arqueólogo coincide com a posição de coleccionador de antiguidades. Como já se referiu, foi em Beja, entre as décadas de 1770 e 1780, que Cenáculo "teve tempo, condições e território para se dedicar de corpo e alma às suas colecções e sobretudo às tarefas de recolhas arqueológicas" (Caetano 1995: 50).

A memória de algumas dessas recolhas e dos passeios arqueológicos pelo sul e litoral alentejanos pode ser lida nalgumas das suas cartas e de vários outros textos, entre eles os Cuidados Literários do prelado de Beja em Graça do seu Bispado [Cenáculo 1791] e o Album de antiguidades lusitanas e luso-romanas (...) de D. Frei Manuel do Cenáculo Villas-Boas: "Lápides do Museo Sezinando Cenaculano Pacense" (apud Patrocínio 2006: 20). Nesta última obra constavam peças provenientes de Beja, Baleizão, Santa Margarida do 
Sado, Torrão, Trigaches, Beringel, Lisboa, Quintos, Moura (Santo Amador), S. Miguel do Pinheiro, Santiago do Cacém, Mértola, Ourique, Tavira, Sines, Tróia e Setúbal (BPE cod. XXXIX / 1-14; apud Caetano 2005: 53).

Como coleccionador de antiguidades e pelas suas actividades arqueológicas, Cenáculo pode ser considerado o primeiro arqueólogo português. Foi efectivamente o primeiro a utilizar a escavação arqueológica, começando pela escavação da Oppidum de Cola (próximo de Ourique, Alentejo). As suas descobertas foram inclusivamente dadas a conhecer na obra Monumenta Linguae Iberae, publicada em 1793.

Depois de uma actividade inicial ligada ao coleccionismo, Cenáculo interessar se-á pelo estudo dos elementos arqueológicos entretanto reunidos. Como referimos, os inícios de uma actividade que poderemos classificar de "arqueológica» dá se em Beja, sobretudo com a intenção de valorizar a cristianização do território. Neste contexto, encetou descobertas e reuniu uma série de peças de diferentes categorias. Não se trata, porém, de um acto isolado. Sobre um pano de fundo eclético, comum aos teóricos portugueses da segunda metade do século XVIII e, em boa medida, às várias correntes europeias das "Luzes», Cenáculo pretendeu consolidar e revalorizar a arte cristã primitiva, postulada pelo romantismo.

Num contexto em que a Igreja sofria duros ataques resultantes das ideias de uma arqueologia romântica e positivista, em particular no que às origens do homem diz respeito, os responsáveis religiosos passaram também a usar a arqueologia para reafirmar a sua antiguidade e a sua legitimidade. Na vizinha Espanha contamos com vários exemplos. Destaque-se em particular - pela sua contemporaneidade com Cenáculo - o prior do Convento de Santiago de Uclés, António de Tavira y Almazán, que promoveu nas últimas décadas do século XVIII escavações na basílica de Segróbriga (ainda não identificada como tal) e descobriu as tumbas dos bispos Sefronio e Nigrino (Maier Allende 2006: 299-349).

Esta ideia está bem expressa na obra de Christopher Woodward, In Ruins (trad. do italiano, 2008: 87), quando refere que «no cristianismo a morte do indivíduo era um prelúdio necessário à ressurreição. As ruínas eram uma metáfora perfeita para este processo..."; "as ruínas de Roma eram um memento mori em escala colossal...". Como ainda refere o autor (Woodward 2008: 88), foi "como símbolo da vitória cristã que os artistas do Renascimento italiano começaram a pintar as ruínas clássicas. Monumentos clássicos em ruínas no fundo de 
obras de arte como o Martírio de São Sebastião de Pollaiuolo e a Natividade de Botticelli simbolizam a passagem do mundo pagão no momento do nascimento de Cristo, e a vitória dos mártires sobre os seus assassinos".

Num estudo de catálogo de Joaquim Oliveira Caetano, intitulado Os Restos da Humanidade. Cenáculo e a Arqueologia (Caetano 2005: 48-56), dá-se a conhecer parte da actividade arqueológica e pioneira de Cenáculo. Deste autor tomamos várias informações. O espólio arqueológico que vinha sendo recolhido por Cenáculo, caso das moedas e medalhas, serviam como prova de antiguidade da presença humana no território alentejano por «hebreus, fenícios e púnicos». A propósito de um conjunto de moedas "Samaritanas fenícias" recolhidas em Tróia e oferecidas pelo desembargador João Vidal de Souza, escreve Cenáculo:

... parece que estas medalhas da extremidade litoral de meo Bispado outro tanto provão de nossos Maiores. Eu creio que ellas tem muita energia. Unidas a outros monumentos descubertos por meo cuidado no Territorio desta Igreja fazem alguma parte dos dezejos diligentissimos na averiguação das antiguidades mais remotas do mundo, que nestes dias cultivam, e adiantão benemeritamente sábios respeitaveis.

Vários são os locais escavados com o patrocínio de Cenáculo, ou realizados por amigos e correspondentes que the fornecem os materiais e os relatórios para o seu estudo. É o caso das necrópoles descobertas na Herdade do Raco( ${ }^{(16)}$ (próximo de Cercal do Alentejo), em Sines, na Herdade do Roxo(17) (Alvalade, Santiago de Cacém), e das escavações continuadas em Tróia, Beja e Almodôvar (Caetano 2005: 51). Noutros locais, como na Herdade da Continha (próximo de Almodôvar) e no Monte de Goes (S. Miguel do Pinheiro, Mértola), recolhe e desenha lápides de chamada escrita do Sudoeste. Noutros casos, ele próprio dirige as escavações, como em Foz da Junqueira, nas proximidades de Sines, e em Tróia (Marcadé 1978: 244). Em Tróia ${ }^{(18)}$, local que identificou como Cetobriga, estranha um achado em particular, uma lucerna paleocristã à qual dá o seguinte significado:

Offerece o mesmo sítio de Tróia outro monumento de ali se conservarem os Netos de Noé, e consiste em huma Lanterna Sepulcral como mostra a Fig. ${ }^{a}{ }^{\circ}$ ․ 7 em memória dos Espias de Jericó, porque não he somente hum caxo ordinario de uvas, como se vê nas medalhas de Acinipo, mas sim huma bem avultada pendura de uvas, como se vê 
nas Medalhas de Acinipo; mas sim huma bem avultada pendura de uvas, e trazida em hombros de dois homens como costumão figurar-se os de que falla a Sagrada Escritura de Jericó, e vem debuxados na Physica Sacra. Tal não he a postura em que se costumão pôr os ministros de Baco em suas imagens (Cenáculo 1946: 238).

Esta lucerna serviu para evocar mais uma vez a tradição orientalizante tão cara a Cenáculo (Patrocínio, 2007-2008: 103). Tróia, entendida a cidade romana de Cetobriga, teria sido fundada por Tubal, um neto de Noé. A lucerna era um testemunho da cultura material deixada por povos antigos vindos do Oriente que teriam usado este local costeiro como porta de entrada para as regiões alentejanas.

Mas é Beja o local privilegiado das suas prospecções. Recolhe das muralhas várias lápides e pedras «romanas, mouriscas e godas»; refere os capitéis do templo; menciona a descoberta de vidros romanos e estátuas, caso do relevo com Hércules em repouso e a já referida estátua sedente feminina que identifica como Cibele (Cenáculo 1946: 441; apud Caetano 2005: 53).

Cenáculo beneficiou ainda de uma vasta rede de contactos que Ihe forneciam novidades das últimas descobertas. É o caso das escavações de Estremoz (no outeiro do castelo na Ribeira de Anna Loira), das inscrições de Idanha-a-Velha, das aras descobertas na igreja de Terena, da descoberta de Miróbriga (Caetano 2005: 53) e de Quintos, a sudoeste de Beja, na via Beja-Mértola, que seguia o trajecto da antiga via romana Pax Iulia-Myrtilis (Marcadé 1978: 243). José Leite de Vasconcelos, ao publicar no Archeologo Portuguez (1985: 338-386) algumas das notas manuscritas de Cenáculo, refere que um tal Francisco José Agoas, proprietário da Herdade de Alvalade (Santiago de Cacém), teria enviado ao prelado três lucernas encontradas naquele local (Marcadé 1978: 243, nota 290).

A par das colecções e da sistemática recolha de objectos de interesse arqueológico, Cenáculo reuniu ainda um considerável conjunto temático de livros que versavam sobre antiguidades e arqueologia. Prestou, enquanto prelado, uma atenção especial à retórica e à eloquência, seguindo as regras elementares da poética do classicismo, num claro compromisso entre o padrão clássico e os princípios da retórica cristã, definidos por Santo Agostinho. A este propósito redigiu um programa de leituras para os noviços do Convento de São Francisco e depois para os seminaristas do Seminário de Beja, em que privilegiou a retórica e os autores clássicos, caso de Quintiliano, 
Horácio, Terêncio, Virgílio, Tito Lívio, Ovídio, entre outros (Vaz 2004: 483-498).

$\mathrm{Na}$ já referida Biblioteca Real Mesa Censória - futura Real Biblioteca Pública da Corte, iniciada nos anos 1770-1775 e aberta ao público no dia 13 de Maio de 1797, data do aniversário do príncipe regente incluíram-se catálogos de colecções e de museus arqueológicos e séries de gravuras, como destaque para as de Giovanni Battista Piranesi, com os Carceri d'invenzione e as Vedute di Roma (Domingos 2006: 31).

A pintura de paisagens viveu um grande momento em Itália graças à procura encetada pelos viajantes do Grand Tour. Os monumentos da antiga Roma eram os temas preferidos pelos numerosos pintores deste género, entre os quais Piranesi (1720 1778), de origem veneziana, afamado artista e antiquário que se especializou como ilustrador e gravador de cenas romanas. A maior parte da sua produção consistia em vedute (vistas), composições de monumentos antigos e contemporâneos dirigidos ao mercado turístico de elite. Além das vedute, que se podiam adquirir soltas ou em série, Piranesi realizou também rigorosos estudos sobre arquitectura romana que incluiu no seu tratado de 1756 Antichità romane (Dyson 2008: 28). Numa época em que a fotografia ainda não existia, a pintura, em particular as vistas das paisagens e ruínas, converteu-se em objecto de prestígio.

Muito fica por dizer sobre Cenáculo. Num relatório datado de 5 de Janeiro de 1796, António Ribeiro dos Santos, lente de Coimbra e ex-bibliotecário de Cenáculo, dá conta do estado lastimável a que tinham chegado os mais de 50000 mil volumes reunidos por este, entre os quais "livros excelentes e de alto custo e muitas colecções de obras valiosas principalmente de História Literária, Crónicas Portuguesas, traduções de Clássicos Gregos e Latinos..." (apud Domingos 2006: 38).

Qualquer que seja o tema em debate sobre esta figura ímpar do Portugal de Setecentos, ficamos com a sensação de incompletude. Para termos uma pequena noção do volume de documentação de $\mathrm{Ce}$ náculo (e sobre Cenáculo), basta consultar a resenha apresentada no final da obra de J. Marcadé, publicada em 1978 sob a chancela da Fundação Calouste Gulbenkian. Que este breve apontamento sirva de inspiração para um futuro estudo sobre Cenáculo no contexto dos primórdios do coleccionismo em Portugal. 


\section{Notas}

(1) Foi dada à estampa, em 2009, uma obra coordenada por Francisco António Lourenço Vaz, intitulada Os livros e as bibliotecas no espólio de D. Frei Manuel do Cenáculo. Repertório de correspondência, róis de livros e doaçôes a bibliotecas. Deste conjunto de documentos salienta-se o facto de Cenáculo ter uma vasta rede de agentes e informadores que lhe permitia estar as par das últimas novidades e, simultaneamente, alimentar a sua bibliofilia.

(2) Segundo J. C. BRIGOLA, Coleccionismo no século XVIII. Textos e documentos, Porto, 2009, v, o Museu moderno é uma aquisição do século XVIII. Na recente obra supracitada, este autor faz uma reflexão teórica sobre o universo museal setecentista, acompanhada por um significativo número de fontes de extremo interesse.

(3) O interesse de Cenáculo pelo coleccionismo é, no entanto, anterior à sua chegada a Beja. Emílio Hübner, nas Noticias archeologicas, dá conta que, em 1772, Cenáculo possuía em Lisboa uma bela colecção epigráfica, apud J. MARCADÉ, Frei Manuel do Cenáculo Vilas Boas. Évêque de Beja, Archevêque d'Évora (1770-1814), Paris, 1978, 242, nota 282.

(4) Um dos quadros encomendados por Pio VI ao pintor francês Bénigne Gagnereau (1756-1795), onde se representa a recepção do monarca sueco Gustavo III sob a cúpula do Museu do Vaticano, tem servido como argumento a favor do lugar central ocupado pelo Museu na retórica do Ancien Regime, ainda antes dos efeitos da Revolução Francesa; J. C. BRIGOLA, Coleccionismo no século XVIII. Textos e Documentos, Porto, 2009, v.

(5) Refira-se, em particular, a Geschichte der Kunst des Alterthums ("História da Arte na Antiguidade»), obra que elevou a História da Arte a nova disciplina científica, M.-L. ROCHEBRUNE, "O gosto "à grega" ou a primeira fase do Neoclassicismo francês", in $O$ gosto "à grega». Nascimento do Neoclassicismo em França (1750-1775), Lisboa, 2008, 15.

(6) Veja-se a transcrição integral deste diploma em J. C. BRIGOLA, Coleccionismo no século XVIII. Textos e documentos, Porto, 2009, 1.

(7) Apenas dois anos antes, em 1748, iniciavam-se as escavações em Pompeia, destinadas a enriquecer as colecções de antiguidades da realeza napolitana, M.-L. ROCHEBRUNE, "O gosto "à grega" ou a primeira fase do Neoclassicismo francês", in O gosto "à grega". Nascimento do Neoclassicismo em França (1750-1775), Lisboa, 2008, 15.

(8) Esta viagem está descrita em BPE, Cod. CX 1-10, Diário da Jornada a Roma. Segundo alguns autores este texto pode não ser de Cenáculo, F. A. L. VAZ et al., Os livros e as bibliotecas no espólio de D. Frei Manuel do Cenáculo. Repertório de correspondência, róis de livros e doações a bibliotecas, Lisboa, 2009, 15, nota 11.

(9) Curador da Biblioteca Vaticana e Prefeito da Congregação do Index. Ver J. C. BRIGOLA, «Frei Manuel do Cenáculo - Semeador de Bibliotecas e de Museus. O conceito de Biblioteca-Museu na museologia setecentista" in AAVV, Frei Manuel do Cenáculo Construtor de Bibliotecas, Casal de Cambra, 2006, 53.

(10) Numa carta datada de 31 de Janeiro de 1783, Cenáculo começa por dizer que não pensa voltar a Roma mas que ainda tem bem presente algumas recordações dessa viajem, F. A. L. VAZ et al., Os livros e as bibliotecas no espólio de D. Frei Manuel do Cenáculo. Repertório de correspondência, róis de livros e doações a bibliotecas, Lisboa, 2009, 21.

(11) Esta expressão deve-se a Richard Lassels, um sacerdote católico que viajou em várias ocasiões em Itália na qualidade de tutor, tendo-a registado no seu diário de viagem, Voyage in Italy, publicado em 1670, E. H. ERCOLI, Grand Tour. II viaggio di formazione lungo la Via Lauretana, Milano, 2008, xix. 
(12) Poucos anos antes, em 1743, foram expedidos alguns "objectos naturais portugueses" para o Museu da Academia das Ciências de Bolonha. A transcrição integral deste documento encontra-se na já referida obra de J. C. BRIGOLA, Coleccionismo no século XVIII. Textos e documentos, Porto, 2009, 4-5.

(13) Depois desta viagem ambos se empenharam no estudo e aprofundamento das línguas grega e hebraica. Num documento conservado na Biblioteca Pública de Évora consta que passado um ano dessa viagem, em 1751, Cenáculo surpreende a assistência ao introduzir numerosas citações em grego na cadeira de Teologia que regia na Universidade de Coimbra (BPE, $116 \mathrm{~V}$, apud J. MARCADÉ, Frei Manuel do Cenáculo Vilas Boas. Évêque de Beja, Archevêque d'Évora (1770-1814), Paris, 1978, 18.

(14) Sobre a figura de Leonor da Fonseca Pimentel veja-se T. SANTOS, S. MARQUES PEREIRA, coords., Leonor da Fonseca Pimentel. A Portuguesa de Nápoles, Lisboa, 2001.

(15) Celebrava-se o Capítulo Geral em Roma, presidida pelo grande Papa humanista Benedicto XIV, um dos maiores letrados do seu tempo que se fazia rodear de sábios e homens das letras, J. MARCADÉ, Frei Manuel do Cenáculo Vilas Boas. Évêque de Beja, Archevêque d'Évora (1770-1814), Paris, 1978, 16.

(16) Deste local provém a peça em bronze com a figuração de uma serpente, ver M. F. S. PATROCÍNIO, "O registo das antiguidades lusitânicas do Sul no legado documental de D. Manuel do Cenáculo", Promontoria, 2006, 28.

(17) Nesta necrópole recolheu moedas e três lucernas, uma das quais the pareceu comportar uma inscrição grega. Cenáculo refere ainda restos de estruturas de um muro, interpretado como um possível lagar (M. F. S. PATROCÍNIO, "O registo das antiguidades lusitânicas do Sul no legado documental de D. Manuel do Cenáculo", Promontoria, 2006, 28).

(18) Por falta de tempo e, sobretudo, por questões financeiras, Cenáculo não pôde dar continuidade à exploração de Tróia como havia desejado, J. MARCADÉ, Frei Manuel do Cenáculo Vilas Boas. Évêque de Beja, Archevêque d'Évora (1770-1814), Paris, 1978, 244. $O$ desenho original desta lucerna encontra-se na Biblioteca Pública de Évora, no COD. CXXIX/1-10, masso fol., com o N. ${ }^{\circ} 124$, intitulado Desenhos e monumentos pertencentes à vida de $S$. Sizenando.

\section{Bibliografia}

ARATA, F. P., "La diffusione e l'affermazione dei modelli artistici dell'antichità. II ruolo del Museo Capitolino nella Roma del Settecento", in Ricordi dell'Antico. Sculture, porcellane e arredi all'epoca del Grand Tour, Milano, 2008, 60-71.

BRIGOLA, J. C., Colecções, Gabinetes e Museus em Portugal no século XVIII, Lisboa, 2003.

BRIGOLA, J. C., «Frei Manuel do Cenáculo - Semeador de Bibliotecas e de Museus. O conceito de Biblioteca-Museu na museologia setecentista", in AAVV, Frei Manuel do Cenáculo - Construtor de Bibliotecas, Casal de Cambra, 2006, 47-55.

BRIGOLA, J. C., Coleccionismo no século XVIII. Textos e documentos, Porto, 2009.

CAEIRO, F. G., Frei Manuel do Cenáculo. Aspectos da sua actuação filosófica, Lisboa, 1959.

CAETANO, C. C., "Esculturas de pequeno formato na vida familiar. Bronzes e terracotas", in AAVV, Imagens e Mensagens. Escultura Romana do Museu de Évora, Évora, 2005, 97-107. 
CAETANO, J. O., "Os restos da Humanidade. Cenáculo e a Arquelogia", in AAVV, Imagens e Mensagens. Escultura Romana do Museu de Évora, Évora, 2005, 48-56.

CARDOSO, A. P., A presença Portuguesa em Roma, Lisboa, 2001.

CENÁCULO, F. M. Do, "Sizenando Martyr e Beja sua Pátria (ed. Manuel Joaquim Delgado)", in Arquivo de Beja 3 e ss. 1946.

CHAVES TRISTÁN, F., "Una visión de la numismática desde la Real Academia de la Historia a lo largo del siglo XIX", in J. Beltrán Fortes, B. Cacciotti, B. P. Venetucci (eds.), Arqueología, coleccionismo y antiguedad. España e Italia en el siglo XIX, Sevilla, 2006, 161-182.

DOMingos, M. D., Frei Manuel do Cenáculo e a Biblioteca Pública. O Mecenas, Lisboa, 2006.

DYSON, S. L., En busca del pasado clássico. Un historia de la arqueología del mundo greco-romano en los siglos XIX y XX, Madrid, 2008.

ENCARNAÇÃO, J., "Da invenção de inscrições romanas pelo humanista André de Resende", Biblos 67, 1994, 193-221.

ERCOLI, E. H., Grand Tour. Il viaggio di formazione lungo la Via Lauretana, Milano, 2008.

HIBBERT, C., The Grand Tour, London, 1974.

HÜBNER, E., Notícias Archeológicas de Portugal, Lisboa, 1874.

MAIER ALLENDE, J., "Aureliano Fernández-Guerra, Giovanni Battista de Rossi y la Arqueología Paleocristiana en la segunda mitad del siglo XIX", in J. Beltrán Fortes, B. Cacciotti, B. P. Venetucci (eds.), Arqueología, coleccionismo y antiguedad. España e Italia en el siglo XIX, Sevilla, 2006, 299-349.

MARCADÉ, J., Frei Manuel do Cenáculo Vilas Boas, Évêque de Beja, Archevêque d'Évora (1770-1814), Paris, 1978.

MELEGATI, L., "Giovanni Volpato e il cantiere romano", in Ricordi dell'Antico. Sculture, porcellane e arredi all'epoca del Grand Tour, Milano, 2008, 104-113.

MORA, G., "Coleccionistas españoles en Italia a comienzos del siglo XIX. El monetario de Dámaso Puertas, médico del XIV Duque de Alba", in J. Beltrán Fortes, B. Cacciotti, B. P. Venetucci (eds.), Arqueología, coleccionismo y antiguedad. España e Italia en el siglo XIX, Sevilla, 2006, 435-457.

PATROCÍNIO, M. F. S., "O registo das antiguidades lusitânicas do Sul no legado documental de D. Manuel do Cenáculo», Promontoria 2006, 17-36.

PATROCÍNIO, M. F. S., "Tempos de Fenícios": O tema do orientalismo e suas descobertas nos de D. Manuel do Cenáculo", A Cidade de Évora, 7, 2007-2008, 99-124.

PEREIRA, S. M., "La fuga in Egitto" - Oratória sagrada oferecida a D. Carlota Joaquina de Bourbon (1792). Pretextos de um texto - Nota Histórica", in Leonor da Fonseca Pimentel. A Portuguesa de Nápoles (1752-1799), T. Santos, S. Marques Pereira (coords.), Lisboa, 2001, 115135.

ROCHA-PEREIRA, M. H., "Os vasos gregos: caminhos e descaminhos do coleccionismo português", in Vasos Gregos em Portugal. Colecção Dr. António Miranda. Museu Municipal Abade Miranda. Colecções 1, Santo Tirso, 2008, 47-52. 
ROCHEBRUNE, M.-L., "O gosto «à grega" ou a primeira fase do Neoclassicismo francês", in O gosto "à grega". Nascimento do Neoclassicismo em França (1750-1775), Lisboa, 2008, 13-24.

VAZ, F. A. L., "As bibliotecas e os livros na obra de D. Frei Manuel do Cenáculo", in La Memoria de los Libros. Estudios sobre la historia del escrito y de la lectura en Europa y America, tomo II, Salamanca, 2004, 483-498.

VAZ, F. A. L., "A Fundação da Biblioteca Pública de Évora", in AAVV, Frei Manuel do Cenáculo - Construtor de Bibliotecas, Casal de Cambra, 2006, 57-86.

VAZ, F. A. L., OLIVEIRA, M. F. e MONTEIRO, P., Os livros e as bibliotecas no espólio de D. Frei Manuel do Cenáculo. Repertório de correspondência, róis de livros e doações a bibliotecas, Lisboa, 2009.

VENETUCCI, B. P., "Nuovi aspetti del collezionismo in Italia e Spagna attraverso le esportazioni di antichitàm, in J. Beltrán Fortes, B. Cacciotti, B. P. Venetucci (eds.), Arqueología, coleccionismo y antiguedad. España e Italia en el siglo XIX, Sevilla, 2006, 503-526.

VENTURA, A., "D. Pedro de Sousa Holstein entre Lete e Mnemóside», in Uma Família de Coleccionadores. Poder e Cultura, Lisboa, 2001, 41-63.

WOODWARD, C., Tra le rovine. Un viaggio atraverso la storia, l'arte e la letteratura, Parma, 2008. 